\title{
A Literary and Theological Exploration of the Temptation Account in the Gospel of Luke
}

\author{
Zoe Saulnier \\ Department of Psychology, University of Alberta, Edmonton, Alberta \\ Corresponding author: zsaulnie@ualberta.ca
}

\section{ABSTRACT}

The temptation story found in the New Testament is one of the most famous biblical narratives.

However, this story is often over simplified, and thus, not properly interpreted. There are many

differences between the three versions of the story that tend to be glossed over. Additionally, readers

often miss the true significance of the story due to their lack of knowledge of the Old Testament. The primary goal of this paper is to be an exegesis of the temptation account found in the gospel of Luke.

I aim to specifically highlight the links between the temptation narrative and key aspects of the Old Testament. I also compare and contrast the differences found between the gospels. The secondary goal of this paper is to discuss the theological and practical implications of the temptation story. That is, to delve into the theology surrounding why the temptation narrative is pertinent to our modern-day interpretation of the scriptures. This paper is designed to help readers understand the great significance of the temptation account in both the context of Luke's gospel and within the broader context of the bible.

\section{Introduction}

The temptation account found in the synoptic gospels has a mystical feel to it that is characteristic of the Old Testament (OT). While most readers notice this similarity, many do not realize the significance of this observation. At first glance, the story is simply a fight between good and evil, but with closer examination, the narrative is much more nuanced. The gospel writers draw parallels between the temptations that Jesus faced and key moments in the Old Testament. The importance of the narrative, therefore, can only be understood within the context of the OT. Additionally, while the temptation story appears in all three synoptic Gospels, each rendition is slightly altered. This adds a layer of nuance to our understanding of the purpose of this story.

The goal of this paper is to expound the temptation account found in the Gospel of Luke. Specific focus will be placed upon drawing connections between passages in the OT and passages in Luke's Gospel, while explaining the significance 
of these connections. Note that this paper is not argumentative in nature, but rather it takes on an explanatory and exploratory approach.

In this paper, I will first briefly introduce the development of the concept of the devil from the time of First Temple Judaism (ca. 1200-586 B.C.E.) till the time of the writing of the Gospels (ca. 70 C.E.). This will be done to help ground the reader in an understanding of the role that the devil filled during the time period of the Gospels. Second, I will use compare-and-contrast methodology to discuss differences across the three temptation accounts found in the Gospels, drawing attention primarily to the aspects unique to Luke's Gospel. Within this analysis, important external differences (e.g. placement in the Gospel) and internal differences (e.g. the order of the temptations) will be acknowledged. ${ }^{1}$ Third, there will be an exegetical analysis of the temptation account in Luke which focuses on connections between the temptation narrative and passages in the OT. Lastly, theological analysis will be applied to the temptation account to help readers understand the importance of this story in its context.

\section{Historical Jewish views of Satan}

The concept of śātān (as transliterated from the Hebrew) was already a complex one by the time the canonical Gospels were written. ${ }^{2}$ It was used in the OT as both a noun (used twentysix times) and a verb (used six times - meaning to slander or to accuse). This mixed use of the word implies a rich understanding of its meaning existed before the New Testament was written. Note, the term 'devil' or 'diabolos' is the translation from the Hebrew to Greek. It is found in the Septuagint (LXX) and the New Testament. ${ }^{3}$

In First Temple Judaism, angels served as messengers between heaven and earth. ${ }^{4}$ Satan was considered one of those angels. Specifically, as seen in the later parts of the OT (i.e. in Job, Chron, and Zech.), one who was testing or in opposition with mankind. ${ }^{5}$ In Job 1 and 2, the only instances in the OT where God and Satan converse, God asks Satan if he knew of Job a "blameless and upright man" (Job 1). ${ }^{6}$ Satan remarked that God had "put a fence around [Job]" (1:10) protecting him from trials, and further stated that if Job was tested, he would curse God. God gave Satan power over all that Job owned and allowed him to do as he pleased with this power (Job 1:11). However, since Satan's power was both granted and limited by God, the implication is that Satan could only act with divine permission. ${ }^{7}$

In the Second Temple Period (539 BCE- 70 CE), Jewish beliefs about Satan underwent a tangible shift as Jews attempted to reconcile their experience of exile with their belief in God. Stories started to develop to explain the origin of demons and the devil. ${ }^{8}$ The first of these, found in 1 Enoch 6-16, claimed that the sons of heaven (angels) had illegitimate intercourse with young human girls. These girls then gave birth to giants (1 Enoch 7 ). The giants were thought to be of the same nature as the Nephilim in Genesis 6:6 who had previously drowned in Noah's flood. ${ }^{9}$ The leader of the new Giants was called Asazel or Beelzebub - the prince of demons - and was the devil. ${ }^{10}$ This story was influential in the time of Luke as the name Beelzebub is used in Luke 11:15 when the people accuse Jesus of casting out demons through the devil's power.

The second story is found in 2 Enoch 29, and appears to have been inspired by Isaiah 14:4-20 and Ezekiel 28:11-19. ${ }^{11}$ It states that on the second day of creation, an archangel named Lucifer, "thought up the impossible idea, that he might place his throne higher than the clouds which are above the earth, and that he might become equal to [God's] Power" (2 Enoch 29). The Lord then hurled him and his followers from heaven and he, Lucifer, was made to fly "above the Bottomless" (29). Lucifer was then known as the devil or Satan. This story introduces the potent theme of idolatry, which is revisited in the third temptation in Luke's temptation account. There, once again, the devil 
asks to be worshiped in the same way as God. By the time that Luke wrote his Gospel, the ideas surrounding the devil or Satan came from a hodgepodge of sources. The stories mentioned above are the ones that seemed to most obviously influence Luke's Gospel, but they were by no means the only ones in existence.

\section{Differences Across the Temptation Accounts}

Mark introduces the temptation account in the first chapter of his Gospel in comparison to Matthew and Luke, who both insert an infancy narrative before their temptation stories. ${ }^{12}$ Despite the macro difference in placement, the micro context is the same: all three versions are preceded by the story of Jesus' baptism by John. Luke places the genealogy and the introduction of the commencement of Jesus' ministry ("[He] was about thirty years old when he began his work" (3:23)) between the baptism and the temptation. ${ }^{13}$ Jesus' ministry is then revisited directly after the temptation account when Jesus begins to teach in the synagogues (4:15). This deliberate sandwiching implies that the temptation works as a discrete piece within the Gospel of Luke. ${ }^{14}$

There are two major structural differences between the temptation accounts. First, Mark differs from the highly concordant accounts of Matthew and Luke as he does not include any specific temptation; he simply states that "[Jesus was] tempted by Satan" (1:13). This suggests that Matthew and Luke had mutual access to a second source (perhaps the hypothetical document named Q). Second, while Matthew and Luke both draw on the traditional Jewish understanding that performing an action thrice is indication of the completion of an event, they each order the three temptations differently. ${ }^{15}$ Matthew places the challenge to throw himself from the temple second and the adoration temptation third - Luke reverses this order. Bovon suggests that Luke arranges his tests so that they reflect an increase in severity, culminating with the devil putting "[the] Lord [his] God to the test" (Lk. 4:12). ${ }^{16}$ Plummer alternatively proposes that Luke's rendition maintains the chronological order; however, there is little evidence to defend this. ${ }^{17}$ A second more likely alternative, is that Luke arranged them to reflect Jesus' journey, which started in the wilderness and ended in Jerusalem. ${ }^{18}$ This is buttressed when one notices that Luke is the only Gospel to explicitly state the beginning of Jesus's journey to Jerusalem - "he set his face towards Jerusalem" (Lk. 9:51). This accentuation helps defend the argument that Luke ordered his temptations to match the crescendo of the narrative. It is also interesting to note that Luke's temptation order follows the sequence found in Deuteronomy 6:11-15 - eating, worshipping God, and then testing God. This suggests that the Exodus narrative may have an even greater influence on Luke's narrative than it did on Matthew's or Mark's.

Mark provides a simple introduction to the temptations, which Matthew and Luke then expand. Despite the Matthean and Lukan accounts being very similar, Luke's ordering of the individual temptations reflect Jesus' journey to Jerusalem.

\section{The Temptation in Luke}

\author{
4:1-2: Jesus, full of the Holy Spirit, returned \\ from the Jordan and was led by the Spirit in \\ the wilderness, where for forty days he was \\ tempted by the devil. He ate nothing at all \\ during those days, and when they were over, \\ he was famished.
}

In the opening verse, Luke noticeably emphasizes the presence of the Holy Spirit by mentioning it twice (Jesus is both filled with the Spirit and is led by the Spirit) whereas the Matthean and Markan counterparts only mention it once. This addition connotes that Jesus is not acting alone during the temptations. Nonetheless, it is clear that being accompanied by the Spirit does not undermine Jesus' role in the narrative. ${ }^{19}$ Rather, it denotes that his actions are completed in accordance with God's 
plan. ${ }^{20}$ This becomes important when evaluating the goal that the devil had in tempting Jesus. The devil, as a fallen angel, knows that Jesus is the Son of God. It is illogical to suggest the tests functioned to prove Jesus's identity to the devil. Besides, just before the temptations, God declared that Jesus was his Son (Lk. 3:22). Green suggests instead that as God's agent, Jesus should be committed to his eschatological agenda; the devil was trying to lure Jesus into veering from God's will. ${ }^{21}$ For example, he told Jesus to change a stone into bread in order that Jesus may be relieved from his famished state - a state needed to show that, unlike Israel in the desert, Jesus was loyal to God through hardship. ${ }^{22}$ Then, the devil offered Jesus the "kingdoms of the world" (Luke. 4:5) in exchange for worshiping him. This is to change the timing of what was promised in Psalm 2:8: "Ask of me, and I will make the nations your heritage, and the ends of the earth your possession." If Jesus had accepted the offer, he would have shifted his allegiance away from God. ${ }^{12}$

4:3-4: The devil said to him, "If you are the Son of God, command this stone to become a loaf of bread." Jesus answered him, "It is written, 'One does not live by bread alone."

The first temptation links physical tribulation (in this case starvation) with faith in God. Jesus was not minimizing the physical needs of humans, nor was he above those needs since he "felt famished" (4:2). Since he was both fully human and fully divine, Jesus felt hunger but had the wisdom to understand that the body needed more than nutritional sustenance - it needed spiritual nourishment.

A temptation regarding hunger would have had a special meaning to Christians familiar with the Exodus story. In Exodus 16 the Israelites were fleeing from Egypt in the desert. They were hungry and complaining. The Lord provided mana and instructed them to only take what they needed for that day; however, they did not trust God, and so they disobeyed him. ${ }^{24}$ Jesus' experience of hunger in the desert would have been interpreted as a redoing of the trials that the Israelites faced. The key difference, however, is that where the Israelites failed to trust in God, Jesus succeeded. This contrast is made more meaningful when readers are aware of a quote found earlier in Exodus: "This is what the Lord says: Israel is my firstborn son" (4:27). Israel, and thus the people of Israel, were named as being the son of God. Jesus, also called the Son of God, righted the wrong that the Israelites had done when they failed to trust God. This successful completion of the temptation would have helped make it clear to early Christians who Jesus truly was. He was not simply another prophet. He was the Son of God who had been sent to fulfill the scriptures.

There are two key differences between the Exodus story and Jesus' temptation account: what led the going into the wilderness, and the entity performing the testing. In Exodus, it was due to the Egyptians and it was God who was testing his people's trust. In the New Testament, it is the Holy Spirit that leads Jesus to the wilderness and the devil that tests him. This accentuates both the importance that the Spirit plays in the Gospel and a shift in understanding of the devil's identity. Instead of the hardship stemming from God, it comes from the devil. This is reflective of the previously mentioned Jewish shift in understanding of the devil which occurred during their exile.

Another related reference to the OT, found in this temptation, strengthens the above connection. Jesus directly quotes the first half of Deuteronomy $8: 3$ by stating, "one does not live by bread alone." The significance of this becomes more clear in the context of the second half of the quote: “... but by every word that comes from the mouth of the Lord." Jesus here is making it abundantly clear that he is righting the wrong-doing of the Israelites who did not trust the word of God. He embodied the quote and demonstrated the importance of following the word of God. 
4:5-8: Then the devil led him up and showed him in an instant all the kingdoms of the world. And the devil said to him, "To you I will give their glory and all this authority; for it has been given over to me, and I give it to anyone I please. If you, then, will worship me, it will all be yours." Jesus answered him, "It is written, 'Worship the Lord your God, and serve only him."'

In the second temptation, the devil offers to give Jesus immediate power over the "kingdoms of the world" (Luke. 4:5). ${ }^{25}$ Two issues arise from this: that of who has true authority over the world, and that of desire for immediate gratification over waiting for the appointed time. The devil uses the same two verbs (paradidōm (to surrender), didōmi (to give)) as those used in Deuteronomy 7 when God promised to "give" (Deut. 7:23) the nations to Israel. ${ }^{26}$ By doing this, the devil is claiming to have complete authority over what he does not. In the story of Job, the devil was granted power. This power was not truly his; rather, it was on loan. Much in the same way, the devil did not have unrestricted power over the earth and, as such, did not have the authority to give that power to another. Hughes, however, suggests that the devil could give what he offered in this temptation because, in several instances, the devil is called the "ruler of this world" (Jn. 12:31; 14:30; 16:11), and "God of this world" (2 Cor. 4:4). However, he fails to acknowledge that the devil's power is severely limited in ways that God's is not. In John and 2 Corinthians, the devil is described as ruler/God of this world, while God himself does not have limitations placed on him. Further, a look at Revelation 20 shows that God can bind (20:2), release (20:7) and incinerate (20:10) the devil. ${ }^{27}$ This stresses the extent of God's control over the devil, and is reflective of a more First Temple Judaism understanding of the dynamic between the devil and God.

The desire for immediate gratification is a theme that occurs in all of the Gospels. This temptation offers Jesus instantaneous rewards for worshipping the devil rather than God. Jesus rejects this offer and chooses to wait till the appointed time: after the resurrection. In Matthew 28:18 during the commissioning of the disciples, Jesus said, "all authority in heaven and in earth has been given to me". It is crucial to notice the difference in rewards that Jesus could have received from the devil, and those that he did receive from God. The devil offered power over the kingdoms of the world, but God provided Jesus with authority over the kingdoms of earth and the kingdoms of heaven.

Judas was also faced with a version of this, and through his failing, directly betrayed Jesus. Hetrusted in mammon more than God, and subsequently, was weak when "Satan entered [him]" (Lk. 22:3). The results of Judas giving in to this temptation led to Jesus' death, and as such, it was imperative that Jesus modeled a way to overcome this temptation.

Jesus also repeatedly dissuades us from either claiming to be worthy of worship, or from worshipping other false gods. Acts 5:36 and 12:23 are efficacious examples of what happens to those who are not loyal to the Lord. The original commandment is made explicit in the temptation account when Jesus quotes Deuteronomy 6 to the devil: "it is written, 'Worship the Lord your God, and serve only him"' (Lk. 4:8). The quote serves to reference both the command given by God to the Israelites in Exodus 20, and their failing to observe this command (when they worshipped the golden calf in Exodus 32). Once again, Jesus successfully completes a temptation that the Israelites failed. This has very similar importance to that described in the previous temptation. Jesus is once again demonstrating that he is the Son of God and that he is the fulfillment of the scriptures.

4:9-13: Then the devil took him to Jerusalem, and placed him on the pinnacle of the temple, saying to him, "If you are the Son of God, throw yourself down from here, for it is written, 'He will command his angels concerning you, to protect you,' and 
'On their hands they will bear you up so that you will not dash your foot against a stone."' Jesus answered him, "It is said, 'Do not put the Lord your God to the test.'" When the devil had finished every test, he departed from him until an opportune time.

In the third temptation, the devil attempts to pit Jesus' previous dedication and trust in God against him by quoting Psalm $91 .{ }^{28}$ By urging him to jump, he is strong-arming Jesus into either denying God, or giving in to the temptation and committing the sin of pride. Further, the devil is challenging Jesus as the Messiah. Pekikta Rabbati says, "our teachers have taught, when the King, the Messiah, reveals himself, he will come and stand on the roof of the temple." ${ }^{29}$ This quote must be taken with the time-period's expectation that the Messiah would perform extraordinary miracles. By refusing the temptation, Jesus is not falling prone to pride, but rather, he is truly being the messiah that God deemed necessary. ${ }^{30}$

The issue of Messianic expectation is raised again when Pilate offers to free either Barabbas or Jesus. Barabbas was described as a "robber" (Jn. 18:40), who took part in an uprising (Mk. 15:7). The Greek word for 'robber' carried political weight and had become synonymous with 'resistance fighter.'31 Ratzinger contends that because Barabbas was described as a "notorious prisoner" (Mt. 27:16) who had committed murder (Lk. 23:19), he was likely a leader of the uprising. ${ }^{32}$ Further, the name Barabbas meant "son of the father". As such, the character of Barabbas carried heavy Messianic connotations by embodying both the role of a leader and the position of the son of the father. ${ }^{33}$ The Jews, when asking for a prisoner to be released, picked the 'Messiah' that used violence in the name of freedom. ${ }^{34}$ They, much like the disciples, could not believe that their true Messiah would come in the form of someone who would suffer and die on the cross, rather than in the form of a strong leader ready to fight for them. ${ }^{35}$
Once again, there are echoes of the Exodus story found in the temptation. The Israelites "quarreled and tested the Lord" (Exod. 17:7) because they thirsted for water and doubted that God was with them. Moses did not trust in the Lord, and so, instead of following the Lord's instructions, he did as he thought was right (see Num. 20.11). Because of their distrust in God, Moses and the Israelites were not able to enter the promised land (Num. 20:12).

When Jesus is faced with the third temptation, he responds by quoting the first half of Deuteronomy 6:16, "do not put the Lord your God to the test." Once again, he overcomes a temptation that the Israelites failed. If one looks at Deuteronomy 6:1819 , there are reasons given as to why one should not test the Lord. It states that if you do what is right and good, one may "go in and occupy the good land that the Lord swore to your ancestors". This parallel elucidates that when Jesus trusted in God, he made his entry into heaven possible.

\section{Purpose of the Temptation Narrative}

Many individuals, upon reading the temptation narratives, question their purpose in the grand scheme of Jesus' earthly life. Why did he need to be tempted in the ways that he was? Pope Emeritus Benedict XVI wrote that Jesus had to be tempted so as to overcome sin and restore man's harmony with God. ${ }^{36}$ This harmony had been broken in the OT when the Israelites failed to trust in the Lord. Jesus had to face these same trials and overcomes them so that he could shoulder his lost sheep and bring them home. Because Jesus himself was "tested by what he suffered, he [was] able to help those who [were] being tested" (Heb. 2:18). This also creates an inseparable link between the baptism and the temptations. Jesus' baptism by John allowed him to be unified with sinners despite not being a sinner himself. By having a "baptism of repentance" (Lk. 3:3) and then being led to be tempted by the devil, Jesus was able to "sympathize with our weaknesses...without [sinning]" (Heb. 4:15). 
In a similar way, the passion narrative is tightly coupled to the temptations. For example, the devil in the temptation repeatedly said to Jesus, "if you are the Son of God...". Similarly, when Jesus was hanging from the cross, passersby taunted and tested him saying, "if you are the King of the Jews, save yourself!" (Lk. 23:37). ${ }^{37}$ However, if Jesus had given in to any of these taunts, he would have been abandoning God's will.

Another suggestion regarding the purpose of the temptation account is that it showed the people of the time that Rome is not the enemy - Satan was. $^{38}$ There was intense political and religious unrest between the early Christians and the Roman Empire. Christians were persecuted and routinely made to suffer for their faith. Wright suggests that Jesus could not have been indifferent to the political tensions between the Jewish people and the Romans. ${ }^{39}$ He would have witnessed the systematic political, economic, and military oppression the Romans imposed on them. And as a Jew, Wright suggests, Jesus would have been tempted to be the kind of Messiah that they were hoping for (rather than the one God commanded). ${ }^{40}$ However, Jesus did not fall prey to the temptation of an immediate acceptance by the people that surely would have accompanied him if he had changed to act like an 'expected' Messiah. By trusting God, and not directing his Messianic resources against Rome, he showed that the real enemy was the devil. ${ }^{41}$

This argument is strengthened by the similarities between the Roman reign and the time that the Jews spent in Egypt. The Exodus story referenced in the first temptation occurred after having being freed from slavery by the Egyptians. The people had faced great oppression and considered the enemy to be the Egyptians. In Luke, the driving force behind the beginning of the temptations, as aforementioned, was the Spirit, and it was Satan who was framed as the enemy. By not having a narrative where Jesus fights the Romans, but by using one where he fights Satan, it indicates that it is in fact the devil who is the enemy.

\section{Conclusion}

The main goal of this paper was to explore and investigate the meaning of the temptation narrative within Luke's Gospel. I first started by explaining how the historical Jewish views of Satan had changed from the period of First Temple Judaism to the time of the Gospels. This was done to emphasize how the idea of the devil was complicated and was still changing. Then, I highlighted the major differences between the three temptation accounts. Within this section, I explained the implications of these differences and showed how Luke's specific formulation of the account modulated its meaning within his Gospel. The third section of this paper was an indepth examination of Luke's temptation narrative. It aimed to highlight the various links that Luke was drawing between the OT and Jesus's temptations. These links are incredibly important when it comes to fully understanding the purpose of the narrative. Finally, I discussed some interpretations of the overall purpose of the temptation narrative.

The temptation story is important when it comes to understanding Jesus as the Son of God and thus the fulfillment of the scriptures. The richness in parallels between the OT stories and Jesus' story can only be understood when the reader realizes that Jesus truly is the Christ. This truth was central to the early Christians and shaped the way in which the Gospels were written. However the importance of these references is often lost on a modern reader. As such, my analysis of the temptation account in Luke's gospel tried to make these oft overlooked implications clearer. 


\section{Notes}

1. It must be noted that Markan priority is assumed in this paper.

2. Jeffrey Burton Russell. The Devil: Perceptions of Evil from Antiquity to Primitive Christianity (Ithaca: Cornell University Press. 1997), 228.

3. Watson, D. F, "Devil," in The Anchor Yale Bible Dictionary, ed. D. N. Freedman (New York: Doubleday, 1992), 183-184.

4. Paula Fredriksen. Sin: The Early History of an Idea (Princeton: Princeton University Press, 2012$), 54$.

5. Fredriksen, Sin: The Early History of an Idea, 54.

6. All bible verses come from the NRSV.

7. Hamilton, V. P. (1992). "Satan," in The Anchor Yale Bible Dictionary, edited by D. N. Freedman (New York: Doubleday, 1992), 985-989.

8. Spangenburg, "A Brief History in the Devil (950 BCE- 70 CE)," Studia Historiae Ecclesiasticae 39, (2013): 2, 9, 13.

9. Spangenburg, "A Brief History in the Devil (950 BCE- 70 CE)," 13.

10. Spangenburg, "A Brief History in the Devil (950 BCE- 70 CE)," 13.

11. 2 Enoch, accessed March, 2018, http://sonnen.tripod.com/enoch3.html.

12. Luke 4:1-13, Matthew 4:1-11, and Mark 1:12- 13.

13. Mark and Matthew go straight from the baptism to the temptation account.

14. Joel B. Green, The Gospel of Luke. The New International Commentary on the New Testament, edited by Ned B. Stonehouse, F.F. Bruce, Gordon D. Fee (Grand Rapids: William B. Eerdmans Publishing Company, 1997), 194.

15. François Bovon, Luke 1. A Hermeneia Commentary, trans. by Christine M. Thomas, ed. by Hulmut Koester (Augsburg: Fortress Press, 2002), 140.

16. Bovon, Luke 1, 139.

17. Joseph Fitzmyer. The Gospel according to Luke I-IX. The Anchor Yale Bible. Vol 28. (New Haven and London: Yale University Press, 2009), 507.

18. Bovon, Luke 1, 139.

19. Green, The Gospel of Luke, 191.

20. Green, The Gospel of Luke, 191.

21. Green, The Gospel of Luke, 195. Norval Geldenhuys, The Gospel of Luke. The New International Commentary on the New Testament (Grand Rapids: William B. Eerdmans Publishing Company, 1951), 158.

22. Bovon, Luke, 143.

23. Green, The Gospel of Luke, 194.

24. Exodus $16: 4$

25. Luke uses oikoumenē meaning 'inhabited world' in 4:6 instead of Matthew's use of Kosmos (4:8). Susan R. Garrett. The demise of the Devil: Magic and the Demonic in Luke's Writings (Minneapolis: Fortress Press, 1989), 38.

26. John T. Carroll, Luke: A Commentary (Louisville: Westminster John Knox Press, 2012), 103.

27. Hamilton, "Satan," 989.

28. R. Kent Hughes. Luke: That You May Know the Truth (Wheaton: Crossway, 2015), 138.

29. Hughes, Luke: That You May Know the Truth, 139.

30. Hughes, Luke: That You May Know the Truth, 139; Richard B. Vinson, Luke. 114.

31. Joseph Ratzinger (Pope Benedict XVI). Jesus of Nazareth - From the Baptism in the Jordan to the 
Transfiguration, translated by Adrian J. Walker (United States of America: Doubleday, 2007), 40.

32. Ratzinger, Jesus of Nazareth, 40.

33. Ratzinger, Jesus of Nazareth, 40. Ratzinger further explains that the form of the name "Bar-Abbas" had the same form as the name of the leader of the last messianic war: Bar-Kokhba (meaning "son of the star"). 41.

34. Ratzinger, Jesus of Nazareth, 41.

35. See Luke 9:18-22, 44; 18:31-33.

36. Ratzinger, Jesus of Nazareth, 6.

37. See Luke $4: 3,9$

38. N.T. Wright, Jesus and the Victory of God (Minneapolis: Fortress Press, 1992), 457.

39. Wright, Jesus and the Victory of God, 458.

40. Wright, Jesus and the Victory of God, 458.

41. Wright, Jesus and the Victory of God, 459. 


\section{Works Cited}

Bovon, François. Luke 1. A Hermeneia Commentary, translated by Christine M. Thomas, edited by Hulmut Koester. Augsburg: Fortress Press, 2002.

Carroll, John T. Luke: A Commentary. Louisville: Westminster John Knox Press, 2012.

Fitzmyer, Joseph A. The Gospel according to Luke I-IX. The Anchor Yale Bible. Vol 28. New Haven and London: Yale university press, 2009.

Fredriksen, Paula. Sin: The Early History of an Idea. Princeton: Princeton University Press, 2012.

Garrett, Susan R. The demise of the Devil: Magic and the Demonic in Luke's Writings Minneapolis: Fortress Press, 1989.

Geldenhuys, Norval. The Gospel of Luke. The New International Commentary on the New Testament. Grand Rapids: William B. Eerdmans Publishing Company, 1951.

Green, Joel B. The Gospel of Luke. The New International Commentary on the New Testament, edited by Ned B. Stonehouse, F.F. Bruce, Gordon D. Fee. Grand Rapids: William B. Eerdmans Publishing Company, 1997.

Hamilton, V. P. “Satan.” In the Anchor Yale Bible Dictionary, edited by D. N. Freedman, 985-989. New York: Doubleday, 1992.

Hughes, R. Kent. Luke: That You May Know the Truth. Wheaton: Crossway, 2015.

Ratzinger, Joseph (Pope Benedict XVI). Jesus of Nazareth - From the Baptism in the Jordan to the Transfiguration, translated by Adrian J. Walker. United States of America: Doubleday, 2007. Russell, Jeffrey Burton. The Devil: Perceptions of Evil from Antiquity to Primitive Christianity. Ithaca: Cornell University Press, 1997.

Spangenberg, Izak. "A Brief History of Belief in the Devil (950 BCE - 70 CE)." In Studia Historiae Ecclesiasticae 39, (2013): 213-245.

Watson, D. F. "Devil". In the Anchor Yale Bible Dictionary, edited by D. N. Freedman, 183-184. New York: Doubleday, 1992.

Wright, N.T. Jesus and the Victory of God. Minneapolis: Fortress Press, 1992.

Vinson, Richard B. Luke. Smyth and Bible Commentary. Smyth and Helwys publishing. United States of America, 2008.

2 Enoch. Accessed March 2018, http://sonnen.tripod.com/enoch3.html. 